\title{
A PROPóSITO DE AMÉRICO VESPUCCI $\left({ }^{\star}\right)$
}

Apreciador da Revista de História, desde o número inaugural da coleçāo, deparou-se-me no derradeiro distribuido, 11, um artigo do Professor Giuseppe Caraci, que me estarreceu.

Nāo se fazia mister tamanha erudição para metralhar simples jágina de louvor a Américo Vespúcio.

Se estivesse em discussāo apenas o nome do autor, seria dispensável qualquer contestação. Pouco se lhe dá ser increpado de jejuno em matéria atinente a Vespúcio, ou outra das muitas que ignora.

Trata-se, porém. da Revista Brasileira de Geografia, de conceito formado entre os sabedores, que estampou a contribuiçāo increpada de erronia.

Em sua defesa, apenas, alinham-se as razões que talvez nāo sejam despresiveis.

Preliminarmente, releva observar que o tradicional órgāo do Conselho Nacional de Geografia, em homenagem aos especialistas, que operaram no Brasil, relembra-lhe as feições, em retrato a bico de pena, acompanhado de resumida biografia.

Em cada número, abre-se página para os "Vultos da Geografra do Brasil", um nacional e outro estrangeiro.

Acorde com tal orientaçāo, o número 1 , ano XII, do primeiro trimestre de 1950, trouxe a efígie de Alexandre de Gusmāo e Américo Vespúcio, sem cogitar de lembrança de alguma data referente ao florentino, como deduziu o Professor ao insinuar: "dirse-ia. escrito com a intençāo de recordar um centenário".

Nāo houve intuito de indicar aos seus patrícios a comemoração que se avizinhava. Nāo foi essa a causa, pode ficar tranqüilo o insigne censor. No que tange à data de nascimento, de propósito valeu-se o autor de expressão dúbia, que devia completar-se,

(*). - A Revista de História recebeu do Prut. Virgílio Corrêa Filho a presente nota que, como sempre, com muito prazer estampa (E. Simós de Panla). 
como está no borrāo original; haja quem a fixe em 4 ou 9 de março", pois que nāo se convencera ainda de nenhuma afirmativa a respeito.

A tipografia eliminou a alternativa - ou 9 -, como também ocorreu no princípio do artigo, de cujo periodo inicial turvou o sentıdo, prejudicado pelo impressor.

De quantos contribuitam... reduziu-se a: $E$ quantos contribuiram, cuja simples leitura evidencia faltar-lhe completamente articulaçāo lógica, além de viciar a regência.

Ao citar o ano de 1451, näo se amparou o autor em Magnaghi, é certo.

Mas tinha à măo o erudito ensaio Amerigo Vespucci e suas viagens (1949), em cujo prefácio o Professor Thomaz Oscar Marcondes de Sousa declarou: "essa é a tese que com raro bilhantismo, defende o Professor Magnaghi e que nós esposamos por nos parecer a que reune maior número de provas".

Nāo poderá, sem dúvida, ser arguido o Professor paulista de "pouco informado no que diz respeito à recente historiografia Vespuciana", e muito menos de ignorar o "que é sabido há mais de meio século", como o autor dos "Vultos", consoante a condenaçāo do Frofessor Caraci.

Ora, o Professor Marcondes de Souza, cujo saber o crítico exalta, sem the fazer favor algum, pois merece os maiores gabos, começa o capitulo I, à pg. 19, com o período: "Amerigo Vespucci, nascido em Florença, a 9 de março de 1451, era filho de..."

Portanto, a informaçāo dos "Vultos" nāo será total disparate, cm que se espeiha a ignorância do criticado.

Estava abonada por autoridade vespuciana, das maiores que se entregam a tais estudos no Brasil.

Quanto ao restante, o censor nāo impugna a conclusāo, em que o autor se afastou da forma dubitativa, para afirmar:

"Fora de dúvida, entretanto, é que, antes de 1500, conheceu o mar das Antilhas, e depois navegou, a serviço de D. Manuel, ou de mercadores italianos, com os quais mantinha amistosa relação, por longo trecho da costa do Brasil.

Serviu de piloto-mor à Espanha no decursoo do último quatriênio de sua vida, tipicamente renascentista, até sucumbir a 22 de fevereiro de 1512, em Sevilha, após lograr a ventura de assistir à glorificaçāo do seu nome, proposto e adotado para apelidar o continente que se interpunha entre a Europa e a Asia, também designados por titulos femininos, assim como a África.

Nāo houve geógrâfo, em verdade, tão mimado pelas boas fadas, que pudesse ufanar-se de tamanha homenagem, maior que tôdas as obtidas pelos contemporâneos, ainda os mais eminentes; da, classe de Colombo e Pedro Álvares Cabral". 
Bem percebe o autor que o Professor Caraci, ansioso, todavía, como timbra em proclamar, da "superaçāo das ideologias nacionais em nome de uma universal fraternidade", preferiria redaçio diferente, que ampliasse ainda mais a fama do geógrafo italiano.

Lamenta, porém, nāo seguir o seu ensinamento, apesar do tom de proselitismo rompente de expressões categóricas.

"Não é preciso, afirma o douto Professor, cansar-se de repetir, introduzindo esta noçāo nos livros escolares (enquanto nāo poucos dos nossos livros de texto continuem a ignorá-lo) que a pressuposta descoberta do Brasil por Cabral nāo só se realisou com um atraso de cêrca de nove meses com relaçāo à primeira abordada de Vespucci nzquela mesma regiāo (julho-agôsto 1499), mas foi devida exclusivamente ao acaso".

Esta, porém, é outra história, que exigiria maior tempo e espaço para explanaçāo, fora do âmbito desta despretenciosa justificativa da homenagem a Vespucci em têrmos elogiosos, que não se embeberam, todavia, de tāo exaltado fervor quanto desejaria o patriótico censor dos "Vuitos". 